\title{
EFFECTS OF TISSUE HANDLING AND PROCESSING STEPS ON PCR FOR DETECTION OF Mycobacterium tuberculosis IN FORMALIN-FIXED PARAFFIN-EMBEDDED SAMPLES
}

\author{
Denise BARCELOS(1), Marcello F. FRANCO(1) \& Sylvia Cardoso LEÃO(2)
}

\begin{abstract}
SUMMARY
Development and standardization of reliable methods for detection of Mycobacterium tuberculosis in clinical samples is an important goal in laboratories throughout the world. In this work, lung and spleen fragments from a patient who died with the diagnosis of miliary tuberculosis were used to evaluate the influence of the type of fixative as well as the fixation and paraffin inclusion protocols on PCR performance in paraffin embedded specimens. Tissue fragments were fixed for four h to $48 \mathrm{~h}$, using either $10 \%$ non-buffered or $10 \%$ buffered formalin, and embedded in pure paraffin or paraffin mixed with bee wax. Specimens were submitted to PCR for amplification of the human beta-actin gene and separately for amplification of the insertion sequence IS6110, specific from the M. tuberculosis complex. Amplification of the beta-actin gene was positive in all samples. No amplicons were generated by PCR-IS6110 when lung tissue fragments were fixed using $10 \%$ non-buffered formalin and were embedded in paraffin containing bee wax. In conclusion, combined inhibitory factors interfere in the detection of $M$. tuberculosis in stored material. It is important to control these inhibitory factors in order to implement molecular diagnosis in pathology laboratories.
\end{abstract}

KEYWORDS: Tuberculosis; PCR; Diagnosis; Paraffin-embedded tissue.

\section{INTRODUCTION}

Brazil occupies the sixteenth position in the number of tuberculosis cases per year among the 22 countries concentrating $80 \%$ of tuberculosis cases in the world ${ }^{30}$.

Precise and fast diagnosis of tuberculosis is of utmost importance nowadays and standardization of reliable methods for detection of Mycobacterium tuberculosis in clinical samples is a major goal, not only in high-burden countries but also throughout the world.

Detection of the tuberculosis bacillus in clinical and pathology laboratories is usually performed by microscopic observation after ZiehlNeelsen (ZN) staining. This is a rapid and affordable test, but sensitivity is low compared to molecular techniques and it does not allow the identification of the Mycobacterium species present in the specimen ${ }^{6,11}$.

Polymerase Chain Reaction (PCR) is highly specific and sensitive compared to $\mathrm{ZN}$ and culture $\mathrm{H}^{4,6,9,26,29}$. It is also rapid, cheap and can be performed in most clinical and pathology laboratories ${ }^{22}$.

Amplification of the insertion sequence IS6110 has been used for many years for diagnosis of tuberculosis ${ }^{5,20,21,27}$. This element is present in genomes of members of the M. tuberculosis complex. Copy numbers vary from 0 to 25 , integrated in different genome regions ${ }^{5,26,29}$. Its presence in multiple copies is the main advantage for its use, which increases amplification sensitivity. $M$. tuberculosis lacking this insertion sequence would not be detected by PCR-IS6110 but this event is rare, and has not been described in Brazil. Also the absence of this insertion element in other species of mycobacteria impairs its use for diagnosis of diseases caused by non-tuberculous mycobacteria.

Several authors have proposed the use of diagnostic molecular methods using formalin-fixed and paraffin-embedded tissue (FFPE) $)^{9,13,27}$. This material can be stored and represents an important source for both prospective and retrospective studies. PCR can detect DNA in small amounts of biological material and for this reason also it is useful for diagnosis ${ }^{5,6}$.

Nevertheless, there are difficulties in obtaining good results using PCR in FFPE tissue ${ }^{16}$. PCR efficiency in FFPE samples may be influenced by several factors, which affect tissue integrity ${ }^{7,22}$, such as the fixation protocol, the age of the paraffin block, and the presence of endogenous or exogenous inhibitors of the reaction ${ }^{1,7}$.

Optimization of rapid diagnostic tests is an important laboratory goal, especially in developing areas with limited resources. In this work we have compared different protocols for tissue fixation and paraffin

(1) Departamento de Patologia, Universidade Federal de São Paulo, UNIFESP, São Paulo, SP, Brasil.

(2) Departamento de Microbiologia, Imunologia e Parasitologia, Universidade Federal de São Paulo, UNIFESP, São Paulo, SP, Brasil.

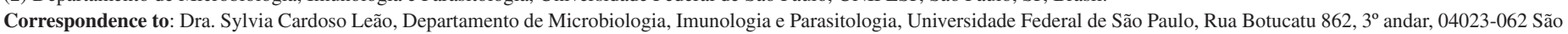
Paulo, SP, Brasil. Tel: 55.11.5576-4537 Fax: 55.11.5572-4711. E-mail: sylvia.leao@unifesp.br 


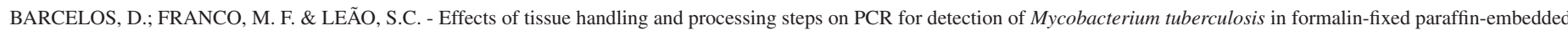
samples. Rev. Inst. Med. trop. S. Paulo, 50(6): 321-326, 2008.

embedding in a controlled experiment for a PCR diagnostic testing for tuberculosis.

\section{MATERIAL AND METHODS}

Samples with controlled fixation and paraffin embedding: Fresh tissue specimens of spleen and lung from an AIDS patient, who died from miliary tuberculosis, strongly positive for acid-fast bacilli, were subjected to different protocols of tissue fixation and paraffin embedding. As negative control, a non-infected block from spleen was tested. Fixation was carried out for $4 \mathrm{~h}, 6 \mathrm{~h}, 12 \mathrm{~h}, 24 \mathrm{~h}$, or $48 \mathrm{~h}$, at room temperature, using formalin phosphate-buffered at $\mathrm{pH} 7.0$ (formaldehyde $37 \%$, monosodic phosphate $47 \mathrm{mM}$, disodic phosphate $28 \mathrm{mM}$ ) or $10 \%$ formalin in distilled water. Embedding was performed using paraffin (Retrowax-Parafinas Nordeste) either pure or mixed with bee wax, 2:1. Table 1 shows the distribution of the different protocols.

Tissue processing for PCR: From each paraffin-embedded specimen, 3 to $10 \mu \mathrm{m}$-thick sections were cut, using a new blade for each sample. Paraffin was extracted with four 30 min incubation with xylol (MERCK, Germany) followed by four washes with $100 \%$ ethanol. Tissue was digested with proteinase $\mathrm{K} 600 \mu \mathrm{g} / \mathrm{mL}$ (final concentration) in TE (Tris-HCl $1 \mathrm{mM}$, EDTA $0.5 \mathrm{mM} \mathrm{pH} \mathrm{8)} \mathrm{and} \mathrm{Tween} 200.5 \%$ for $16 \mathrm{~h}$ at $37^{\circ} \mathrm{C}$. Samples were subjected to heat-shock in liquid nitrogen, for one min, and incubated for $10 \mathrm{~min}$ at $95^{\circ} \mathrm{C}$. DNA was extracted with phenolchloroform-isoamylic alcohol 25:24:1 and precipitated with 10\% sodium acetate $3 \mathrm{M} \mathrm{pH} 4.8$ and 2.5 volumes of absolute ethanol (MERCK). The precipitate was ressuspended in TE plus RNAse and kept at $4{ }^{\circ} \mathrm{C}$. DNA concentration was determined in spectrophotometer at $260 \mathrm{~nm}$ wave length, and purity was evaluated by analysis of readings at $260 \mathrm{~nm}$ and 280 nm (GeneQuant, Amersham Biosciences do Brasil Ltda).

Amplification of human beta-actin gene: A 135 bp fragment of the human beta-actin gene was amplified using $0.5 \mu \mathrm{M}$ of primers $\beta_{5}$ : AGCGGGAAATCGTGCGTG and $\beta_{\mathrm{R}}$ : GGTGATGACCTGGCCGTC in reactions containing $50 \mathrm{mM} \mathrm{KCl}, 10 \mathrm{mM}$ Tris- $\mathrm{HCl}, \mathrm{pH} 8.0,1.5 \mathrm{mM}$ $\mathrm{MgCl}_{2}, 100 \mu \mathrm{M}$ dNTPs, and $1 \mathrm{U}$ of Taq polymerase (Invitrogen). DNA $(0.2 \mu \mathrm{g})$ was amplified with one cycle at $96{ }^{\circ} \mathrm{C}$ for five min, 40 cycles at

Table 1

Results of PCR for amplification of the human beta-actin gene and IS6110 in lung and spleen samples subjected to different fixation and embedding protocols

\begin{tabular}{|c|c|c|c|c|c|c|c|}
\hline \multirow[b]{3}{*}{ fxT (h) } & \multirow[b]{3}{*}{ Tpf } & \multirow[b]{3}{*}{ Incl } & \multicolumn{4}{|c|}{ tissue } & \multirow[b]{3}{*}{$\beta$-actin } \\
\hline & & & \multicolumn{2}{|c|}{ spleen } & \multicolumn{2}{|c|}{ lung } & \\
\hline & & & IS6110 & $\mathrm{H}$ & IS6110 & $\mathrm{H}$ & \\
\hline 4 & F10\% & $\mathrm{Pw}$ & + & + & - & + & + \\
\hline 4 & F10\% & $\mathrm{Pp}$ & + & + & + & + & + \\
\hline 4 & $\mathrm{BF}$ & $\mathrm{Pw}$ & + & + & - & + & + \\
\hline 4 & $\mathrm{BF}$ & $\mathrm{Pp}$ & + & + & - & - & + \\
\hline 6 & F10\% & $\mathrm{Pw}$ & - & + & - & + & + \\
\hline 6 & F10\% & $\mathrm{Pp}$ & + & + & + & + & + \\
\hline 6 & $\mathrm{BF}$ & $\mathrm{Pw}$ & - & + & + & + & + \\
\hline 6 & $\mathrm{BF}$ & $\mathrm{Pp}$ & + & + & + & + & + \\
\hline 12 & $\mathrm{~F} 10 \%$ & $\mathrm{Pw}$ & + & + & - & - & + \\
\hline 12 & F10\% & $\mathrm{Pp}$ & - & - & + & + & + \\
\hline 12 & $\mathrm{BF}$ & $\mathrm{Pw}$ & - & + & - & + & + \\
\hline 12 & $\mathrm{BF}$ & $\mathrm{Pp}$ & + & + & + & + & + \\
\hline 24 & F10\% & $\mathrm{Pw}$ & + & + & - & - & + \\
\hline 24 & F10\% & $\mathrm{Pp}$ & - & + & + & + & + \\
\hline 24 & $\mathrm{BF}$ & $\mathrm{Pw}$ & + & + & - & + & + \\
\hline 24 & $\mathrm{BF}$ & $\mathrm{Pp}$ & + & + & + & + & + \\
\hline 48 & F10\% & $\mathrm{Pw}$ & - & - & - & - & + \\
\hline 48 & F10\% & $\mathrm{Pp}$ & - & + & + & + & + \\
\hline 48 & $\mathrm{BF}$ & $\mathrm{Pw}$ & + & + & + & + & + \\
\hline 48 & $\mathrm{BF}$ & $\mathrm{Pp}$ & - & + & + & + & + \\
\hline
\end{tabular}

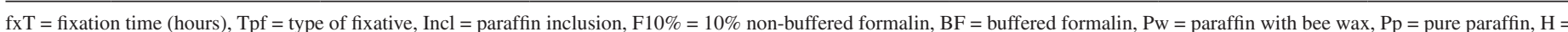
hybridization with probe complementary to IS6110. 


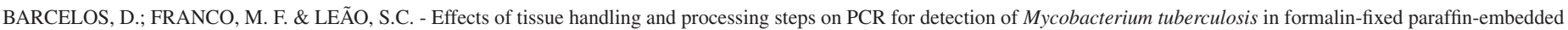
samples. Rev. Inst. Med. trop. S. Paulo, 50(6): 321-326, 2008.

$96{ }^{\circ} \mathrm{C}$ for two $\min , 60{ }^{\circ} \mathrm{C}$ for two min and $72{ }^{\circ} \mathrm{C}$ for two min and a final extension cycle at $72{ }^{\circ} \mathrm{C}$ for seven min.

Amplification of insertion sequence IS6110: A 123 bp fragment from the insertion sequence IS6110 was amplified using $0.5 \mu \mathrm{M}$ of the primers IS1: CCTGCGAGCGTAGGCGTCGG and IS2: CTCGTCCAGCGCCGCTTCGG ${ }^{5}$ in reactions containing $50 \mathrm{mM} \mathrm{KCl}$, $10 \mathrm{mM}$ Tris- $\mathrm{HCl}, \mathrm{pH} 8.0,1.5 \mathrm{mM} \mathrm{MgCl}, 100 \mu \mathrm{M}$ dNTPs, and $1 \mathrm{U}$ of Taq Polymerase. Amplification cycles were one cycle at $96{ }^{\circ} \mathrm{C}$ for five min, 40 cycles at $96{ }^{\circ} \mathrm{C}$ for one min, $65^{\circ} \mathrm{C}$ for one min and $72{ }^{\circ} \mathrm{C}$ for one min and a final extension cycle at $72{ }^{\circ} \mathrm{C}$ for seven min.

Detection of amplification products: PCR products were visualized in $2 \%$ agarose gels in buffer TBE (Tris-borate $45 \mathrm{mM}$, EDTA $1 \mathrm{mM}$ ) under UV light, after electrophoresis at $100 \mathrm{~V} / \mathrm{min}$ and ethidium bromide staining.

Southern blot and hybridization: Amplification products in agarose gels were blotted onto nylon membranes (Hybond N-plus, Amersham Biosciences do Brasil Ltda) using Vacuum Blotter apparatus (BioRad, Hercules, CA, USA). Membranes were incubated in $\mathrm{NaOH} 0.4 \mathrm{~N}$ for two $\min$ and in SSC $0.1 \mathrm{X} / \mathrm{SDS} 0.1 \%$ at $65^{\circ} \mathrm{C}$ for $15 \mathrm{~min}$ (SSC $1 \mathrm{X}$ is 150 $\mathrm{mM} \mathrm{NaCl}, 15 \mathrm{mM}$ sodium citrate $\mathrm{pH}$ 7.0). DNA was probed, in different experiments, with products of amplification of beta-actin and IS6110. Probes were covalently labeled with peroxidase by glutaraldehyde and detected according to the procedure of the ECL Direct System (Amersham Biosciences do Brasil Ltda). Hybridization was visualized after exposure of the membranes to X-ray film (X-OMAT Kodak, Rochester, NY, USA).

\section{RESULTS}

No consistent differences in the quantity of isolated DNA were observed between the samples. Table 1 shows the different specimen preparation protocols and results obtained with PCR reactions and hybridization. PCR of the human beta-actin gene generated amplicons with all 40 tested samples, confirming the presence of amplifiable DNA in all samples (Fig. 1). The different fixation times used (4h, 6h, 12h, $24 \mathrm{~h}$ and $48 \mathrm{~h}$ ) did not influence the amplification results.

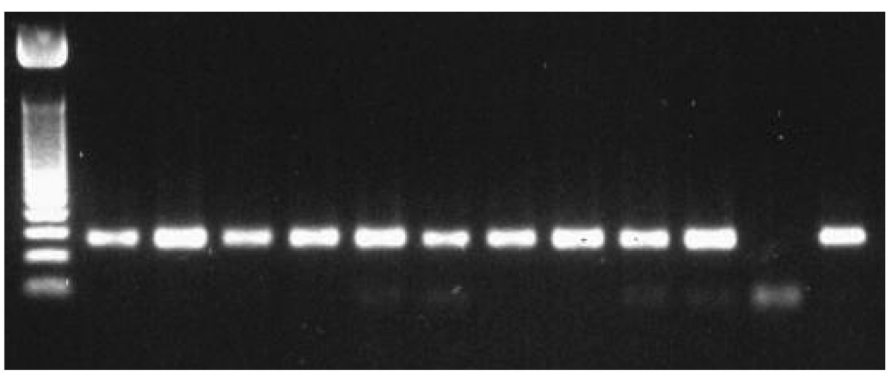

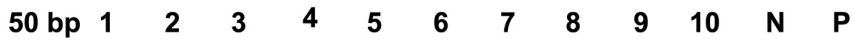

Fig. 1 - Agarose (2\%) gel electrophoresis of amplified beta-actin fragments from 10 lung samples. 1: $4 \mathrm{~h} /$ buffered formalin, 2: $4 \mathrm{~h} / 10 \%$ non-buffered formalin, $3: 6 \mathrm{~h} /$ buffered formalin, $4: 6 \mathrm{~h} / 10 \%$ non-buffered formalin, $5: 12 \mathrm{~h} /$ buffered formalin, $6: 12 \mathrm{~h} / 10 \%$ non-buffered formalin, 7: $24 \mathrm{~h} /$ buffered formalin, 8: $24 \mathrm{~h} / 10 \%$ non-buffered formalin, 9: $48 \mathrm{~h} /$ buffered formalin, 10: 48h / 10\% non-buffered formalin. All samples were embedded in paraffin with bee wax. N: negative control, P: positive control (purified DNA from $M$. tuberculosis $\mathrm{H} 37 \mathrm{Rv}$ ).
Fixation protocols: IS6110 amplicons were visualized in agarose gels with $60 \%$ of the lung specimens fixed in buffered formalin and were detected in $90 \%$ of the same specimens after hybridization of the amplified fragments. When lung specimens were fixed in $10 \%$ non-buffered formalin, positivity of PCR decreased to $50 \%$ by gel visualization and to $70 \%$ after hybridization.

IS6110 amplicons from $70 \%$ of the spleen specimens fixed with buffered formalin were visualized in gel. After hybridization, all specimens gave positive results. Amplicons were visualized in agarose gels with $50 \%$ of the $10 \%$ non-buffered formalin fixation specimens and were detected in $80 \%$ of these specimens after hybridization (Fig. 2A).

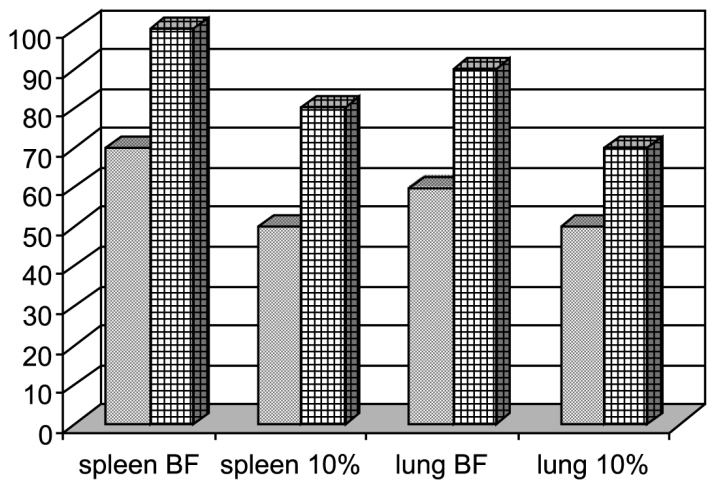

A
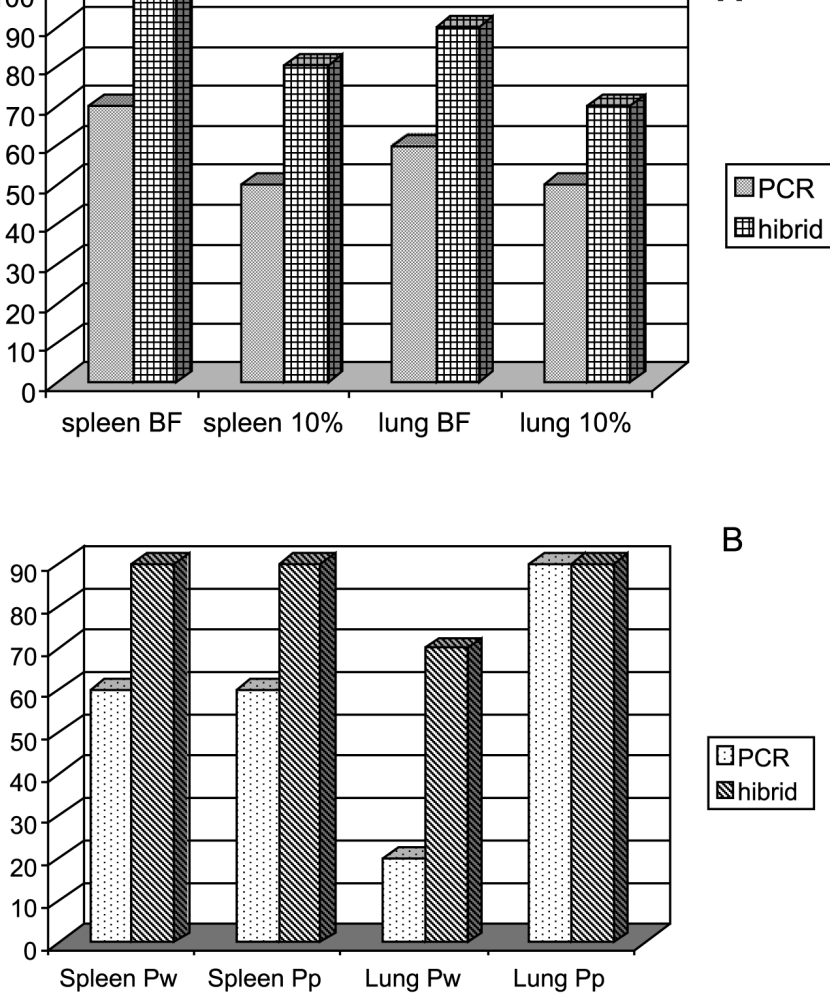

B

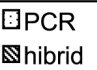

Fig. 2 - A: Positivity of PCR-IS6110 (PCR) and hybridization (hibrid) in lung and spleen specimens fixed with buffered formalin (BF) and 10\% non-buffered formalin (10\%). B: Positivity of PCR-IS6110 (PCR) and hybridization (hibrid) in lung and spleen specimens embedded in paraffin with bee wax $(\mathrm{Pw})$ and pure paraffin $(\mathrm{Pp})$.

Embedding protocols: Lung samples embedded in paraffin with bee wax generated amplicons in $20 \%$ of the analyzed samples, by gel visualization; this percentage increased to $70 \%$ after hybridization. Only one out of 10 samples embedded in pure paraffin was negative in both agarose gel visualization and hybridization (Fig. 2B and Table 1).

No differences were observed when spleen samples embedded in pure paraffin or paraffin with bee wax were compared. Amplicons were visualized in agarose gels with $60 \%$ of the samples and after hybridization with $90 \%$ of the samples (Fig. 2B). In one sample from each group, amplicons not visualized in gels were also negative after hybridization (Table 1). 


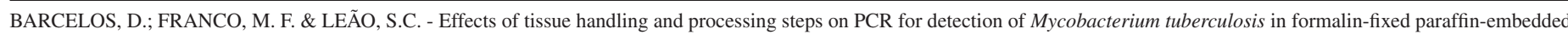
samples. Rev. Inst. Med. trop. S. Paulo, 50(6): 321-326, 2008.

\section{DISCUSSION}

The FFPE procedure is adequate for tissue morphology conservation but may negatively affect nucleic acid preservation and consequently also molecular diagnostic procedures. Analyzable DNA fragments usually have less than $300 \mathrm{bp}$ to $500 \mathrm{bp}$, probably due to strand fragmentation to which RNA is much more susceptible ${ }^{24,28}$. In order to evaluate factors contributing to the low efficiency of PCR in FFPE samples, an experiment using two different tissue types (lung and spleen) and different time of fixation, fixatives, and paraffin embedding protocols was performed. A single protocol for DNA extraction was used, based on that proposed by WRIGHT \& MANOS $^{31}$, but including additional steps of DNA extraction with phenol-chloroform-isoamylic alcohol and ethanol precipitation.

Amplification of the human beta-actin gene, used as control of DNA extraction, was obtained with all samples. The high efficiency of this test might be related to the primers used, which amplify a 135 bp fragment instead of the $404 \mathrm{bp}$ fragment described by RICHTER $e t$ $a l .{ }^{19}$. The size of the amplicon is a decisive factor for the amplification success $^{8}$, because DNA in FFPE tissues is often degraded by fixation and embedding procedures ${ }^{12,23,28}$.

DNA concentration may also influence PCR results. DIAZ et al. ${ }^{4}$ used $0.5 \mathrm{mg}$ to $2 \mathrm{mg}$ of DNA in the tests for the detection of Mycobacterium tuberculosis DNA in tissue and obtained $100 \%$ positive result in all biopsy samples, which were also culture proven cases of tuberculosis. MARCHETTI et al. ${ }^{18}$ tested different DNA concentrations $(1 \mu \mathrm{g}, 3 \mu \mathrm{g}$ and $5 \mu \mathrm{g}$ ) in PCR for amplification of the IS6110 insertion sequence. Best results in terms of sensitivity were obtained with $1 \mu \mathrm{g}$ and $3 \mu \mathrm{g}$ and the highest number of false-negative results was obtained with DNA at a concentration of $5 \mu \mathrm{g}$, probably as a consequence of the presence of inhibitors ${ }^{1,8}$. In this work, we have used $0.2 \mu \mathrm{g}$ of DNA per reaction and this concentration was sufficient to generate beta-actin gene amplicons with all samples.

RISH et al. ${ }^{20}$ suggested that DNA fragmentation in FFPE tissues might be influenced by the fixative and fixation time. In our study, amplification results were not clearly influenced by the different fixation times tested (4h, 6h, 12h, 24h and 48h).

Despite the few numbers of samples fixed for $48 \mathrm{~h}$, apparently there was less interference of the use of non-buffered formalin in the molecular results in the samples fixed longer than $24 \mathrm{~h}$.

In a future project, it would be interesting to test, in a large series, archival samples, fixed in non-buffered formalin and stored for long period of time.

Similar results were obtained by GREER et al. ${ }^{7}$, who evaluated different fixation times (1h, $4 \mathrm{~h}$ and $24 \mathrm{~h}$ ) and by JOHANSEN et al. ${ }^{16}$ who obtained excellent results using fixation times between $16 \mathrm{~h}$ and $18 \mathrm{~h}$. In our experiment, the samples were collected and fixed in less than $24 \mathrm{~h}$, which may have contributed to the high positivity in the human betaactin gene amplification. INOUE et al. ${ }^{14}$ concluded that tissues have to be fixed immediately for one day to remain viable for amplification by PCR of fragments up to 200bp.

Regarding the fixative, buffered formalin presented better results than $10 \%$ non-buffered formalin both with lung and spleen samples, with positivity of $50 \%$ and $50 \%$, respectively. For the samples fixed in buffered formalin, the positivity was $60 \%$ and $70 \%$ for lung and spleen, respectively, which suggested that $10 \%$ non-buffered formalin may be inadequate for samples that will be submitted to molecular biology testing.

Our results paralleled those obtained by MARCHETTI et al. ${ }^{18}$ using FFPE tissues fixed with buffered formalin. Nevertheless, the results differ from those obtained by JOHANSEN et al. ${ }^{16}$, who described good results with the use of $10 \%$ non-buffered formalin. It is possible that the quality of the water used for formalin dilution or other unknown factors might have contributed to these discrepant results. AN et al. ${ }^{1}$ described the presence of PCR inhibitors in frozen samples, indicating that they can be endogenous and not induced by fixation or other steps of specimen preparation.

Bee wax is commonly added to paraffin to facilitate the sectioning of FFPE samples. The presence of bee wax did not influence PCR for human beta-actin gene amplification but influenced negatively the amplification of the M. tuberculosis IS6110 fragment. This was observed in lung tissue, in which amplicons were detected only in $20 \%$ of the samples embedded in paraffin with bee wax against $90 \%$ of the samples embedded in pure paraffin. On the contrary, similar results were obtained with spleen specimens embedded in paraffin with bee wax and pure paraffin.

Hybridization can be used to increase sensitivity of detection of amplification products, especially in paucibacillary samples ${ }^{3,15,25}$. In the present study, IS6110 amplification products from five lung and six spleen samples not visualized in gels were detected after hybridization experiments. However, hybridization failed to detect amplicons obtained with four lung and two spleen samples (Table 1). The present results confirmed overall increase in sensitivity after hybridization; however some authors did not observe any significant increase in sensitivity after hybridization of PCR products ${ }^{5,17}$.

False negative results of IS6110 PCR might have resulted from a low efficiency of the mycobacterial cell wall lysis or uneven distribution of bacilli in the samples ${ }^{1,16}$. In addition, for the testing, only part of biopsy samples were analysed. As the distribution and quantity of bacilli vary from field to field, this might be an additional explanation for false negative results.

False negative results of molecular testing using FFPE tissue have also been described when the fixation protocol is not known ${ }^{10}$, after inadequate fixation ${ }^{2}$, and as a result of excessive dilution of $\mathrm{DNA}^{18}$. To increase the efficiency of cell wall lysis of the organisms, the increase of the temperature as well as the concentration of the proteinase $\mathrm{K}$ might be two helpful technical additional procedures. HEINMOLLER et al. ${ }^{10}$ did not demonstrate the presence of mycobacteria by PCR in FFPE lymph node samples, but amplicons were generated when fresh samples were used.

Considering data presented in Table 1, the number of spleen and lung test samples generating IS6110 amplicons visualized in agarose gels was comparable (12 with spleen and 11 with lung samples). On the other hand, after hybridization, amplicons were detected with 18 spleen samples but only with 16 lung samples. Perhaps the histological organization of the lungs, showing sparse cellularity with respect to organ 
BARCELOS, D.; FRANCO, M. F. \& LEÃO, S.C. - Effects of tissue handling and processing steps on PCR for detection of Mycobacterium tuberculosis in formalin-fixed paraffin-embedded samples. Rev. Inst. Med. trop. S. Paulo, 50(6): 321-326, 2008.

volume, may contribute for the production of insufficient amounts of available mycobacterial DNA ${ }^{1}$.

When the factors that produced negative effect in amplification detection were combined, i.e. specimens fixed with $10 \%$ non-buffered formalin, embedded in paraffin with bee wax, and obtained from lung, positivity of PCR-IS6110 was null. This result indicates that these combined factors profoundly affect the detection of M. tuberculosis in stored paraffin blocks. In conclusion, an effort for implementation of non-inhibiting fixation and embedding protocols has to be made in pathology laboratories in order to put into practice efficient molecular techniques for tuberculosis diagnosis.

\section{RESUMO}

\section{Efeitos das etapas de tratamento e processamento do tecido na PCR para detecção de Mycobacterium tuberculosis em amostras fixadas em formalina e incluídas em parafina}

O desenvolvimento e a padronização de métodos confiáveis para a detecção de Mycobacterium tuberculosis em amostras clínicas é um objetivo importante nos laboratórios de todo o mundo. Neste trabalho, fragmentos de pulmão e baço de paciente que morreu com o diagnóstico de tuberculose miliar foram usados para avaliar a influência do tipo de fixador e dos protocolos de fixação e inclusão em parafina na performance da PCR. Fragmentos de tecido foram fixados por quatro $h$ a $48 \mathrm{~h}$, usando formalina não tamponada a $10 \%$ ou formalina tamponada a $10 \%$ e incluídos em parafina pura ou misturada a cera de abelha. As amostras foram submetidas a PCR para amplificação do gene da betaactina humana e, separadamente, para amplificação da sequência de inserção IS6110, específica do complexo M. tuberculosis. O resultado da amplificação do gene da beta-actina foi positivo em todas as amostras. Não foram gerados amplicons na PCR-IS6110 em amostras de tecido pulmonar fixadas usando formalina não tamponada a $10 \%$ e incluídas em parafina com cera de abelha. Em conclusão, fatores inibitórios combinados interferiram na detecção de $M$. tuberculosis em material de arquivo. É importante controlar estes fatores inibitórios para poder implementar o diagnóstico molecular em laboratórios de patologia.

\section{ACKNOWLEDGMENTS}

This work was supported by Fundação de Amparo à Pesquisa do Estado de São Paulo (FAPESP) Proc. N. 00/06193-5. DB was the recipient of a fellowship from Coordenação de Aperfeiçoamento de Pessoal de Nível Superior (CAPES).

\section{REFERENCES}

1. AN, S.F. \& FLEMING, K.A. - Removal of inhibitor(s) of the polymerase chain reaction from formalin fixed, paraffin wax embedded tissues. J. clin. Path., 44 924-927, 1991

2. CATALOLUK, O.; CAKMAK, E.A.; BUYUKBERBER, N. \& BARLAS, O. Formalin fixing and paraffin embedding may lead to extra band development in PCR New Microbiol., 26: 193-198, 2003.

3. COETSIER, C.; VANNUFFEL, P.; BLONDEEL, N. et al. - Duplex PCR for differential identification of Mycobacterium bovis, M. avium, and M. avium subsp. paratuberculosis in formalin- fixed paraffin-embedded tissues from cattle. J. clin. Microbiol., 38: 3048-3054, 2000.
4. DIAZ, M.L.; HERRERA, T.; LOPEZ-VIDAL, Y. et al. - Polymerase chain reaction for the detection of Mycobacterium tuberculosis DNA in tissue and assessment of its utility in the diagnosis of hepatic granulomas. J. Lab. clin. Med., 127: 359-363, 1996.

5. EISENACH, K.D.; CAVE, M.D.; BATES, J.H. \& CRAWFORD, J.T. - Polymerase chain reaction amplification of a repetitive DNA sequence specific for Mycobacterium tuberculosis. J. infect. Dis., 161: 977-981, 1990.

6. FUKUNAGA, H.; MURAKAMI, T.; GONDO, T.; SUGI, K. \& ISHIHARA, T. Sensitivity of acid-fast staining for Mycobacterium tuberculosis in formalin-fixed tissue. Amer. J. respir. crit. Care Med., 166: 994-997, 2002.

7. GREER, C.E.; LUND, J.K. \& MANOS, M.M. - PCR amplification from paraffinembedded tissues: recommendations on fixatives for long-term storage and prospective studies. PCR Meth. Applic., 1: 46-50, 1991.

8. GREER, C.E.; WHEELER, C.M. \& MANOS, M.M. - Sample preparation and PCR amplification from paraffin-embedded tissues. PCR Meth. Applic., 3: S113-S122, 1994

9. HARDMAN, W.J.; BENIAN, G.M.; HOWARD, T. et al. - Rapid detection of mycobacteria in inflammatory necrotizing granulomas from formalin-fixed, paraffinembedded tissue by PCR in clinically high-risk patients with acid-fast stain and culture-negative tissue biopsies. Amer. J. clin. Path., 106: 384-389, 1996.

10. HEINMOLLER, E.; RENKE, B.; BEYSER, K. et al. - Piffalls in diagnostic molecular pathology-significance of sampling error. Virchows Arch., 439: 504-511, 2001.

11. HOFMAN, V.; SELVA, E.; LANDRAUD, L. et al. - Value of PCR amplification from formalin-fixed paraffin-embedded tissues in the diagnosis of Mycobacterium tuberculosis infection. Ann. Path., 23: 206-215, 2003.

12. HUNT, J.L. - Molecular pathology in anatomic pathology practice: a review of basic principles. Arch. Path. Lab. Med., 132: 248-260, 2008.

13. IKONOMOPOULOS, J.A.; GORGOULIS, V.G.; KASTRINAKIS, N.G. et al. Sensitive differential detection of genetically related mycobacterial pathogens in archival material. Amer. J. clin. Path., 114: 940-950, 2000.

14. INOUE, T.; NABESHIMA, K.; KATAOKA, H. \& KOONO, M. - Feasibility of archiva non-buffered formalin-fixed and paraffin-embedded tissues for PCR amplification: an analysis of resected gastric carcinoma. Path. Int., 46: 997-1004, 1996.

15. JEYANATHAN, M.; ALEXANDER, D.C.; TURENNE, C.Y.; GIRARD, C. \& BEHR M.A. - Evaluation of in situ methods used to detect Mycobacterium avium subsp. paratuberculosis in samples from patients with Crohn's disease. J. clin. Microbiol., 44: 2942-2950, 2006.

16. JOHANSEN, I.S.; THOMSEN, V.O.; FORSGREN, A.; HANSEN, B.F. \& LUNDGREN, B. - Detection of Mycobacterium tuberculosis complex in formalin-fixed, paraffin-embedded tissue specimens with necrotizing granulomatous inflammation by strand displacement amplification. J. molec. Diagn., 6: 231-236, 2004.

17. KRITSKI, A.L. - PCR with DNA from M. tuberculosis in paraffin embedded biopsies of peripheral lymph nodes. São Paulo, 1995. (PhD Thesis - Federal University of São Paulo)

18. MARCHETTI, G.; GORI, A.; CATOZZI, L. et al. - Evaluation of PCR in detection of Mycobacterium tuberculosis from formalin-fixed, paraffin-embedded tissues: comparison of four amplification assays. J. clin. Microbiol., 36: 1512-1517, 1998.

19. RICHTER, E.; SCHLUTER, C.; DUCHROW, M. et al. - An improved method for the species-specific assessment of mycobacteria in routinely formalin-fixed and paraffin-embedded tissues. J. Path., 175: 85-92, 1995.

20. RISH, J.A.; EISENACH, K.D.; CAVE, M.D. et al. - Polymerase chain reaction detection of Mycobacterium tuberculosis in formalin-fixed tissue. Amer. J. respir crit. Care Med., 153: 1419-1423, 1996. 
BARCELOS, D.; FRANCO, M. F. \& LEÃO, S.C. - Effects of tissue handling and processing steps on PCR for detection of Mycobacterium tuberculosis in formalin-fixed paraffin-embedded samples. Rev. Inst. Med. trop. S. Paulo, 50(6): 321-326, 2008.

21. SALIAN, N.V.; RISH, J.A.; EISENACH, K.D.; CAVE, M.D. \& BATES, J.H. Polymerase chain reaction to detect Mycobacterium tuberculosis in histologic specimens. Amer. J. respir. crit. Care Med., 158: 1150-1155, 1998.

22. SCHOOLNIK, G.K. - Applications and transfer of technology to the nations of the South. Biotechnology and the control of childhood enteric infections. Infect. Dis. Clin. North Amer., 5: 265-275, 1991.

23. SEN GUPTA, R.; HILLEMANN, D.; KUBICA, T. et al. - HOPE-fixation enables improved PCR-based detection and differentiation of Mycobacterium tuberculosis complex in paraffin-embedded tissues. Path. Res. Pract., 199: 619-623, 2003.

24. TALAULIKAR, D.; GRAY, J.X.; SHADBOLT, B.; MCNIVEN, M. \& DAHLSTROM, J.E. - A comparative study of the quality of DNA obtained from fresh frozen and formalin-fixed decalcified paraffin-embedded bone marrow trephine biopsy specimens using two different methods. J. clin. Path., 61: 119-123, 2008.

25. TANSUPHASIRI, U.; BOONRAT, P. \& RIENTHONG, S. - Direct identification of Mycobacterium tuberculosis from sputum on Ziehl-Neelsen acid fast stained slides by use of silica-based filter combined with polymerase chain reaction assay. J. med. Ass. Thailand, 87: 180-189, 2004.

26. THIERRY, D.; BRISSON-NOEL, A.; VINCENT-LEVY-FREBAULT, V. et al. Characterization of a Mycobacterium tuberculosis insertion sequence, IS6110, and its application in diagnosis. J. clin. Microbiol., 28: 2668-2673, 1990.
27. VAGO, L.; BARBERIS, M.; GORI, A. et al. - Nested polymerase chain reaction for Mycobacterium tuberculosis IS6110 sequence on formalin-fixed paraffin-embedded tissues with granulomatous diseases for rapid diagnosis of tuberculosis. Amer. J. clin. Path., 109: 411-415, 1998

28. VAN MALDEGEM, F.; DE WIT, M.; MORSINK, F. et al. - Effects of processing delay, formalin fixation, and immunohistochemistry on RNA recovery from formalinfixed paraffin-embedded tissue sections. Diagn. molec. Path., 17: 51-58, 2008.

29. VAN SOOLINGEN, D.; HERMANS, P.W.; DE HAAS, P.E.; SOLL, D.R. \& VAN EMBDEN, J.D. - Occurrence and stability of insertion sequences in Mycobacterium tuberculosis complex strains: evaluation of an insertion sequence-dependent DNA polymorphism as a tool in the epidemiology of tuberculosis. J. clin. Microbiol., 29: 2578-2586, 1991.

30. WORLD HEALTH ORGANIZATION - Tuberculosis. http://www.who.int/ mediacentre/factsheets/fs104/en/index.html

31. WRIGHT, D.K. \& MANOS, M.M. - Sample preparation from paraffin-embedded tissue In: INNIS, M.A. PCR protocols: a guide to methods and applications. Berkeley, Academic Press, 1990. p. 153-158.

Received: 7 May 2008

Accepted: 20 October 2008 